\title{
A New Galactose-Specific Lectin from Clerodendrum infortunatum.
}

\author{
Sukumaran Surya, Madhathilkovilakathu Haridas*
}

Inter University Centre for Bioscience and Department of Biotechnology and Microbiology, Kannur University, Thalassery Campus, Kannur 670661, India

"Corresponding author: Madhathilkovilakathu Haridas, Inter University Centre for Bioscience and Department of Biotechnology and Microbiology, Kannur University, Thalassery Campus, Kannur 670661, India, Tel/ Fax: 049-0 2347394, E-mail: mharidasm@rediffmail.com

Received: 13 Jan. 2016; $\quad$ Revised: 19 Apr. 2018; $\quad$ Accepted: 17 Jun. 2018; $\quad$ Published online: 12 Dec. 2018

\begin{abstract}
Background: The ethno-medical significance of Clerodendrum genus raises the interest towards the characterization of its seed lectin by inexpensive and most effective technique.

Objective: The focus of this study is the purification, characterization, and evaluation of the antioxidant and antiproliferative potential of a galactose-specific lectin from Clerodendrum infortunatum L. seeds.

Materials and Methods: The crude extract, homogenized in 6 volumes of the saline containing 10 mM $\beta$-mercaptoethanol was subjected to pigment removal by Toyopeal HW-55 column prior to ammonium sulfate fractionation (40-80\%). The crude protein extract was then loaded to the gel filtration column Sephadex G-200 followed by affinity chromatography using activated galactose coupled Sepharose-4B.

Results: The SDS-PAGE analysis showed a single band of about $30 \mathrm{kDa}$ which further determined by MALDI-TOF analysis. The MALDI-TOF spectra revealed that Clerodendrum infortunatum lectin (CIL) is a homo-tetramer of $120 \mathrm{kDa}$ consisting of four identical subunits of $30 \mathrm{kDa}$. The haemagglutination inhibition assay was done with purified lectin by many sugars, among which N-acetyl-D-galactosmine (NAG), D-galactose and lactose exhibited high inhibition. NAG showed the highest inhibition amongst the tested sugars, having the minimum inhibitory concentration of about $0.97 \mathrm{mM}$. The lectin exhibited a moderate antioxidant activity with an $\mathrm{IC}_{50}$ value of $6.1 \pm 0.1 \mathrm{mg} \cdot \mathrm{mL}^{-1}$ and induced cell death with $\mathrm{IC}_{50}$ of $82.8 \mu \mathrm{g} \cdot \mathrm{mL}^{-1}$ against human gastric cancer cell line, AGS, indicated the potential of CIL for clinical and therapeutic applications.

Conclusion: The present study demonstrated the moderate ability of the CIL to inhibit the growth of human gastric cancer cells, AGS either by causing cytotoxic or anti-proliferative effects. Thus, CIL due to its remarkable properties may be considered as a potential bio-molecule in tumor research and glycobiology.

Keywords: Anti proliferative, Clerodendrum. infortunatum Lectin, Glycoproteins, Haemagglutination, Lectins.
\end{abstract}

\section{Background}

Lectins are glycoproteins of non-immune origin (1, 2 ), possessing at least one non catalytic domain which binds reversibly to a specific monosaccharide or oligosaccharide (3). Owing to their cell agglutinating property they are commonly referred to as phytohaemagglutinins $(4,5)$. The plant lectins have gained much attention because of their ubiquitous presence and applicability as glycoconjugates. Isolation and purification of lectins could be carried out through a variety of purification strategies depending on their source, structure, physiochemical properties, specificity, and biological activity. Lectin sources of plants may be the seeds, roots, fruits, flowers or leaves. Legume lectins represent the largest and most thoroughly studied family of lectins which consists of two or four monomers, either identical or slightly different, each with a single, sugar binding site (6). Lectins play essential role in many biological processes like cell-cell recognition events such as host defense, fertilization, tumor metastasis, embryogenesis, mitogenic simulations, innate immune response, and protein trafficking $(5,7,8)$. Lectins

Copyright (C) 2018 The Author(s); Published by National Institute of Genetic Engineering and Biotechnology. This is an open access article, distributed under the terms of the Creative Commons Attribution-NonCommercial 4.0 International License (http://creativecommons.org/licenses/ by-nc/4.0/) which permits others to copy and redistribute material just in noncommercial usages, provided the original work is properly cited. 
may serve as useful tools for characterization of the glycoproteins, histochemistry of the cells, tissues, and for examination of changes occurred on cell surfaces during pathological changes undergoing in malignancy from cell differentiation to tumor formation (7). The topology of the cell organelles with carbohydrates coat can be marked by specific surface binding property of the lectins. Such lectins are extensively used as cytochemical and histochemical probes to label mammalian cells (6). Certain plant lectins could be useful as tools to distinguish between malignant and benign tumors through their ability to determine the metastatic condition via their degree of glycosylation (9).

Elucidation of lectin-carbohydrate interactions at the molecular level (10) and the anti-tumor potential of lectins like Concanavalin A (Con A), Phaseolus vulgaris, phytohaemagglutinin-L (PHA-L), Wheat germ agglutinin (WGA), Polygonatum odoratum lectin (POL), Soyabean lectin and Griffonia simplicifolia agglutinin (GSA) by inhibiting the proliferation of the different malignant cell lines (11-17) has made the lectins extensively useful elements in the research and diagnostics. Con A, the first reported legume lectin, shows apoptosis in the human melanoma A375 cells and autophagy inducing activities mediated by the cytochrome c release. Con A entered the preclinical trials due to its apoptotic and autophagic properties (18). The Clerodendrum infortunatum (Family-Lamiaceae) is a flowering shrub found rich in constituents, such as clerodolone, clerodone, clerosterol, flavonoids, terpenoids, saponins, phenolics, and sugars $(20,21)$. The genus is widely distributed in the tropical and subtropical regions. Moreover, it is used in many systems of the medicine such as Ayurveda, Homeopathy, Siddha, and Unani, for ailments like alopecia, diarrhea, skin disorders, asthma, and postnatal complications. It is well-known for its hepato-protective and antimicrobial activities (22-24). Consequently, the ethno-medical significance of the diverse species of the Clerodendrum genus raises the interest towards characterization of its seed lectin. Hence, the present work aimed to study a lectin from Clerodendrum infortunatum using a simple and most effective technique, mainly focusing on further characterization via determination of its antioxidant and antiproliferative potential towards gastric-carcinoma cell lines. The early reports on Clerodendrum trichotomum agglutinin (CTA) illustrates the purification and the primary characterization of a lectin from clerodendrum genus shown an insight towards this goal (25). In light of the earlier findings on plant lectins, we undertook the present study to purify and characterize a novel lectin from Clerodendrum infortunatum (CIL) with the potential of the applications.

\section{Objectives}

A galactose specific lectin from Clerodendrum infortunatum was purified and characterized via biochemical means and its antioxidant and antiproliferative potential was discussed.

\section{Materials and Methods}

\subsection{Preparation of Crude Protein Extract}

Clerodendrum infortunatum seeds were collected from the nearby locality of Kannur University Campus in Kannur district, Kerala, India and authenticated by the authority of the Botany department, Govt. Brennen College, Dharmadam, Thalassery. A voucher specimen (MH/DBM 005 2012) was prepared and deposited at the Department of Biotechnology, Kannur University, Kerala for future reference. Samples were washed, air dried and stored at $4{ }^{\circ} \mathrm{C}$. Seeds of Clerodendrum infortunatum $(100 \mathrm{~g})$ were homogenized in 6 volumes of the saline containing $10 \mathrm{mM} \beta$-mercaptoethanol in a mortar and pestle. In order to alleviate the enzymatic browning of the extract a small amount of polyvinylpyrolidine was added. The sonicated slurry was stirred at $4{ }^{\circ} \mathrm{C}$ overnight and filtered through cheese cloth. The slurry was subjected to centrifugation at $10,000 \times g$ at $4{ }^{\circ} \mathrm{C}$ for 30 minutes and filtered through Whatman No.1 filter paper for removal of floating lipids. The dark brown colored supernatant obtained after centrifugation was subjected to the pigment removal.

\subsection{Pigment Removal from the Crude Extract}

Pigment removal from the crude extract performed by the Toyopeal HW-55 column (Sigma-Aldrich, United States). The dark brown color of the extract, due to the presence of pigments, was found to be interfering with the conventional galactose specific columns. Removal of the pigments before performing size exclusion or affinity column chromatography was essential for the protein purification.

\subsubsection{Activation of the Toyopearl HW-55 Column}

The Toyopearl HW-55 (25 mL) was suspended in 40 $\mathrm{mL}$ aniline in the presence of sodium cyanoborohydride $\left(450 \mathrm{mg}\right.$ ) and was incubated at $37{ }^{\circ} \mathrm{C}$ for 24 hours. The unreacted formyl groups were reduced by adding sodium borohydride $(250 \mathrm{mg})$. The extract was then passed through the activated Toyopearl HW-55 column 
pre equilibrated with $6 \%$ saline for effective removal of pigments hindering the lectin-binding capacity to the affinity adsorbent. Then early colorless filtrate obtained after passing through the absorbent column was used for purification of the lectin $(25,26)$.

\subsection{Purification of the Lectin}

Lectin from the crude seed extract of the Clerodendrum infortunatum was purified based on the protocol reported by Kitagaki et al. (25) with slight modifications. The crude seed extract was subjected to ammonium sulfate precipitation method and most of the lectins was precipitated at $40-80 \%$ of ammonium sulfate solvent. Then the fraction was subjected to the centrifugation at $10,000 \times g$ at $4{ }^{\circ} \mathrm{C}$ for $15 \mathrm{~min}$. The supernatant was discarded and the precipitate was collected and dissolved in $20 \mathrm{mM}$ phosphate buffered saline (PBS), $\mathrm{pH} 7.2$ and was subjected to the dialysis (dialysis tube cutoff- $20 \mathrm{kDa}$ ) with the same buffer for further purification.

\subsubsection{Gel Filtration - Sephadex G-100}

The crude extract was loaded onto the $20 \mathrm{mM}$ PBS equilibrated Sephadex G-100 column and eluted at a flow rate of $8 \mathrm{~mL}$ per hour with the same buffer, at $4{ }^{\circ} \mathrm{C}$. Fractions were collected and checked for haemagglutinating activity. The protein was monitored by measuring absorbance at $280 \mathrm{~nm}$. The fractions with haemagglutination activity were pooled out and subjected to further purification events.

\subsubsection{Affinity Chromatography - Galactose Coupled Sepharose- $4 B$}

For further purification of the protein, the pooled protein fractions showing haemagglutination, obtained after gel filtration were subjected to the affinity chromatography with galactose coupled Sepharose-4B as per the protocol of Franco-Fraguas et al. (27) with slight modifications. Sepharose-4B (20 g) was incubated in $0.4 \mathrm{M} \mathrm{NaOH}$ and $5 \%$ epichlorohydrin at $40{ }^{\circ} \mathrm{C}$ for 2 hours. The activated matrix was washed and incubated in $0.1 \mathrm{M} \mathrm{NaOH}$ and $10 \%$ galactose for 2 days at room temperature. Reactive epoxy groups were blocked by incubating for 4 hours at room temperature in $1 \mathrm{M}$ ethanolamine. The fractions obtained after dialysis against $20 \mathrm{mM}$ PBS, was applied to activated, galactose-coupled Sepharose4B column, previously equilibrated with the same PBS at $4{ }^{\circ} \mathrm{C}$. The adsorbed proteins were eluted from the column with the PBS containing $0.2 \mathrm{M}$ galactose and checked for haemagglutinating activity. The fractions exhibiting haemagglutination were pooled, dialyzed, and subjected to the characterization. The end point of the assay, visually estimated after an hour and the minimum protein concentration required for agglutinating human Red Blood Cells (RBCs), was expressed as the haemagglutination titer $(28,29)$. The reciprocal of the highest dilution of the lectin exhibiting haemagglutination was defined as the haemagglutination titer. The specific activity is the number of haemagglutination titers per milligram of protein (30).

\subsection{Biophysical and Biochemical Characterization of the Lectin and Molecular Weight Determination}

\subsubsection{SDS-Polyacrylamide Gel Electrophoresis (SDS $P A G E)$}

The molecular weight of the purified lectin was determined by SDS-PAGE, using the broad range molecular weight marker on $12 \%$ polyacrylamide gel containing $1 \%$ SDS in the presence of $\beta$-mercaptoethanol at a constant voltage of $120 \mathrm{~V}(31,32)$.

\subsubsection{MALDI-TOF Mass Spectrum and Iso-Electric Focusing (IEF) Analysis}

The mass spectrum was recorded on Shimadzu Biotech Axima-CFR $^{\mathrm{TM}}$ Plus MALDI mass spectrometer (Shimadzu, Japan) in the linear positive ion mode using sinapinic acid as the matrix. The mass spectrum was acquired by using $19 \mathrm{KV}$ acceleration voltage. A total of 500 scans were averaged for the final spectrum.

The $\mathrm{pI}$ of the lectin was determined by using Rotofor (preparative iso electric focusing cell-Bio-Rad). About $0.5 \mathrm{~mL}$ of the lectin extract was mixed with $1 \mathrm{~mL}$ of ampholyte (pH 3-10 Bio-Rad) and $18.5 \mathrm{~mL}$ of the distilled water. After degassing, the mixture was loaded onto a mini chamber with a syringe, and supplied a $12 \mathrm{~W}$ to the chamber. A gradual increase in voltage (from $300 \mathrm{~V}$ to $500 \mathrm{~V}$ ) for 3 hours was monitored. After attaining resultant voltage stability, the separated samples were vacuum harvested as $2 \mathrm{~mL}$ fractions. The $\mathrm{pH}$ of collected fractions was read subsequently and assayed for haemagglutination activity.

\subsubsection{Haemagglutination Activity Study}

Haemagglutination assay was performed on microtitre plate using trypsinised human RBCs. The RBCs were washed twice in PBS to get a cell suspension of $2 \%$ in the same buffer. The haemagglutination activity of the protein solution after affinity column in PBS was determined. About $0.2 \mathrm{~mL}\left(2 \mathrm{mg} \cdot \mathrm{mL}^{-1}\right)$ of the lectin solution was serially diluted with PBS and each dilution was mixed with equal volume of $2 \%$ RBCs suspension and incubated for about 1 hour at room temperature. Results were examined visually (33). 


\subsubsection{Haemagglutination Inhibition Study}

The haemagglutination inhibition test was done in the presence of series of sugars including NAG, D-galactose, lactose, D-fructose, D-mannose, D-galactosamine, D-arabinose, D-glucose, maltose, D-fucose, D-ribose, and sucrose of about $0.2 \mathrm{M}$ concentration. The assay was performed on the microtitre plate by adding $50 \mu \mathrm{L}$ of the sugar solution $(0.2 \mathrm{M})$ serially diluted by PBS followed by the addition of $50 \mu \mathrm{L}$ of the purified lectin (2 mg.mL $\mathrm{m}^{-1}$ ), needed for visible agglutination, to each well. After incubation at $37{ }^{\circ} \mathrm{C}$ for an hour, $50 \mu \mathrm{L}$ of the $4 \%$ human $\mathrm{RBC}$ was added and the mixture was allowed to stand for further 1 hour at room temperature. Reactions were compared with a negative control (50 $\mu \mathrm{L}$ sugar solution $+50 \mu \mathrm{L}$ PBS $+50 \mu \mathrm{L} 4 \%$ human $\mathrm{RBC})$. The minimum concentration of sugar required to inhibit haemagglutination was recorded. The $\mathrm{IC}_{\mathbf{1 0 0}}$ is the minimum concentration required for $100 \%$ inhibition of the CIL (34).

\subsubsection{Effect of Temperature and $\mathrm{pH}$ on the Lectin- Induced Haemagglutination}

Thermal denaturation study was performed by incubating the purified lectin $\left(2 \mathrm{mg} \cdot \mathrm{mL}^{-1}\right)$ at various temperatures, ranging from $10{ }^{\circ} \mathrm{C}$ to $100{ }^{\circ} \mathrm{C}$ for 30 minutes. The $\mathrm{pH}$ dependent haemagglutination activities of CIL were performed by pre-incubating the samples at different $\mathrm{pHs}$, ranging from 2 to 10 . A buffer cocktail including $50 \mathrm{mM}$ glycine- $\mathrm{HCl}(\mathrm{pH}$ 2-3), $50 \mathrm{mM}$ sodium acetate/acetic acid ( $\mathrm{pH} 4-5), 50$ $\mathrm{mM}$ sodium phosphate/ $\mathrm{HCl}(\mathrm{pH} 6-7), 50 \mathrm{Mm}$ Tris$\mathrm{HCl}(\mathrm{pH}$ 8) and $50 \mathrm{mM}$ glycine- $\mathrm{NaOH}(\mathrm{pH} 9-10)$ were used for testing $\mathrm{pH}$ stability. The thermal and $\mathrm{pH}$ dependent haemagglutination treatments were performed with $50 \mu \mathrm{L}$ aliquots of the lectin solution at room temperature. A graph was plotted for $\mathrm{pH} /$ temperature vs. haemagglutination activity.

\subsection{Determination of Total Sugar Content of the Lectin} The total neutral sugar content of the purified lectin was estimated by anthrone method using D-glucose as the standard (35). CIL solution ( $\left.2 \mathrm{~mL}, 2 \mathrm{mg} \cdot \mathrm{mL}^{-1}\right)$ was hydrolyzed/denatured into its monomers by keeping it in a boiling water bath for 3 hours in the presence of $5 \mathrm{~mL}$ of $2.5 \mathrm{~N} \mathrm{HCl}$. It was then neutralized by adding pinches of solid sodium carbonate until the effervescence ceased. The supernatant after centrifugation was used for further analysis. Anthrone gave colored compound with simple sugars, the digested products. The amount of total carbohydrate present in the test sample was estimated from the absorbance plotted against a glucose standard curve at $578 \mathrm{~nm}$.

\subsection{DPPH Free Radical-Scavenging Assay}

The 2,2-Diphenyl-1-picrylhydrazyl (DPPH) free radical scavenging activity of CIL was performed according to Paixao et al. (36). CIL solutions of the various molarity (i.e., 2, 4, 6, 8, and $10 \mathrm{mg} \cdot \mathrm{mL}^{-1}$ in $20 \mathrm{mM}$ PBS, $\mathrm{pH}$ 7.2) were added to an equal volume of $(10 \mathrm{~mL})$ methanolic solution of DPPH (400 $\left.\mu \mathrm{g} \cdot \mathrm{mL}^{-1}\right)$. Ascorbic acid (2-10 $\left.\mathrm{mg} . \mathrm{mL}^{-1}\right)$ was considered as reference standard. After incubation at room temperature in dark for $30 \mathrm{~min}$, the absorbance of the resulting solution was measured at 517 $\mathrm{nm}$ using UV-Vis Spectrophotometer (Model. U.2800, Hitachi, Japan) against the control. An equal volume of DPPH solution was taken as the control for the radical scavenging assay. All experimental measurements were carried out in triplicate and expressed as average of three analyses \pm standard deviation. The free radical scavenging activity was measured by the following equation. $\mathrm{IC}_{50}$ value, defined as the concentration of antioxidant, required for $50 \%$ scavenging of DPPH radicals in the specified time period, was determined graphically $(37,38)$.

DPPH radical-scavenging activity $(\%)=$ $\left(\mathrm{A}_{\mathrm{c}}-\mathrm{A}_{\mathrm{s}}\right) / \mathrm{A}_{\mathrm{c}} \times 100 \quad$ Equation 1 where, $A_{c}=$ Absorbance of control, $A_{s}=$ Absorbance of sample.

\subsection{Assay of Anti-Proliferative Activity on Gastric Cancer Cell Line}

The 3-(4, 5-dimethylthiazol-2-yl)-2,5-diphenylt etrazolium bromide (MTT) assay was performed with human gastric cancer cell line, AGS obtained from ATCC. The AGS cell line was cultured in Dulbecco's Modified Eagle Medium (DMEM) supplemented with $10 \%$ fetal bovine serum. For assay on AGS cell lines the cells were adjusted to a cell density of $8 \times 10^{4}$ cells $/ \mathrm{mL}$ in DMEM. The cells $(100 \mu \mathrm{L})$ were seeded onto each well of a 96-well plate and incubated overnight at 37 ${ }^{\circ} \mathrm{C}$ in the presence of $5 \% \mathrm{CO}_{2}$. Varying concentrations of CIL prepared using 2-fold serial dilution of about 3.1-200 $\mu \mathrm{g} \cdot \mathrm{mL}^{-1}$ were added to each well followed by incubation at $37{ }^{\circ} \mathrm{C}, 5 \% \mathrm{CO}_{2}$ for 48 hours. After incubation, the medium was discarded and $25 \mu \mathrm{L}$ of MTT ( $5 \mathrm{mg} \cdot \mathrm{mL}^{-1}$ ) was added to each well, followed by incubation for 3 hours. Dimethyl sulfoxide (DMSO) of about $150 \mu \mathrm{L}$ was added to each well to dissolve the MTT formazan formed at the bottom of the wells. All measurements were carried out in triplicate and are expressed as average of three analyses \pm standard deviation.The optical density (OD) was measured at $570 \mathrm{~nm}$ and the percentage inhibition of the cells was calculated by the following equation (39). 
Table 1. Purification yields of various chromatographic fractions of CIL.

\begin{tabular}{|c|c|c|c|c|c|}
\hline Fractions & $\begin{array}{c}\text { Total Protein } \\
\text { (mg) }\end{array}$ & $\begin{array}{c}\text { Haemagglutination } \\
\text { activity (titer) }\end{array}$ & $\begin{array}{l}\text { Specific activity } \\
(\text { titer.mg-1) }\end{array}$ & Yield (\%) & $\begin{array}{c}\text { Purification } \\
\text { fold }\end{array}$ \\
\hline 1. Crude extract & 600 & 4500 & 7.5 & 100 & 1 \\
\hline 2. After Toyopeal HW-55 column & 552 & 4250 & 7.7 & 94.4 & 1.023 \\
\hline 3. After $80 \%\left(\mathrm{NH}_{4}\right)_{2} \mathrm{SO}_{4}$ fraction & 210 & 3281 & 15.62 & 72.91 & 2.082 \\
\hline 4. After Sephadex G-100 column & 62 & 1937 & 31.24 & 43.04 & 4.165 \\
\hline 5. After affinity column & 12.5 & 895 & 71.6 & 20.00 & 9.54 \\
\hline
\end{tabular}

The percentage of inhibition $(\%)=$ Treated OD value / OD value of the untreated control $\times 100$. Equation 2

\section{Results}

\subsection{Purification of CIL Lectin}

The $80 \%$ ammonium sulfate fractionated crude protein extract after dialysis against $20 \mathrm{mM}$ PBS was applied to an activated pigment absorbent column Toyopeal HW-55. The brown colored pigment in the crude protein extract was effectively adsorbed by Toyopeal HW-55. Almost a colorless crude protein effluent was subjected to the Sephadex G-100 column at $4{ }^{\circ} \mathrm{C}$ which was previously equilibrated with the same buffer. The active fractions showing haemagglutination activity were pooled and purified further by affinity chromatography on activated galactose coupled Sepharose-4B. The other fractions devoid of haemagglutination were not used for further analysis as they contained a small amount of protein having significant biological activity. The overall purification data was summarized in Table 1.

\subsection{SDS-PAGE}

The fractions obtained after affinity chromatography on galactose coupled Sepharose-4B column gave a single band of about $30 \mathrm{kDa}$ on $12 \%$ SDS-polyacrylamide gel electrophoresis in the presence of $\beta$-mercaptoethanol indicating that it was a pure protein (Fig. 1).

\subsection{MALDI-TOF Mass Spectrum and Iso-Electric Focusing (IEF) Analysis}

The MALDI-TOF mass spectrum analysis of the CIL showed prominent peaks at $30 \mathrm{kDa}$ and $120 \mathrm{kDa}$ indicated the presence of homodimers. Therefore, it was revealed that CIL is a homo dimer and form tetrameric association in solution with the apparent molecular weight of 120 kDa (Fig. 2).

After running preparative IEF, the $\mathrm{pH}$ of the harvested protein was monitored and recorded. IEF revealed that the

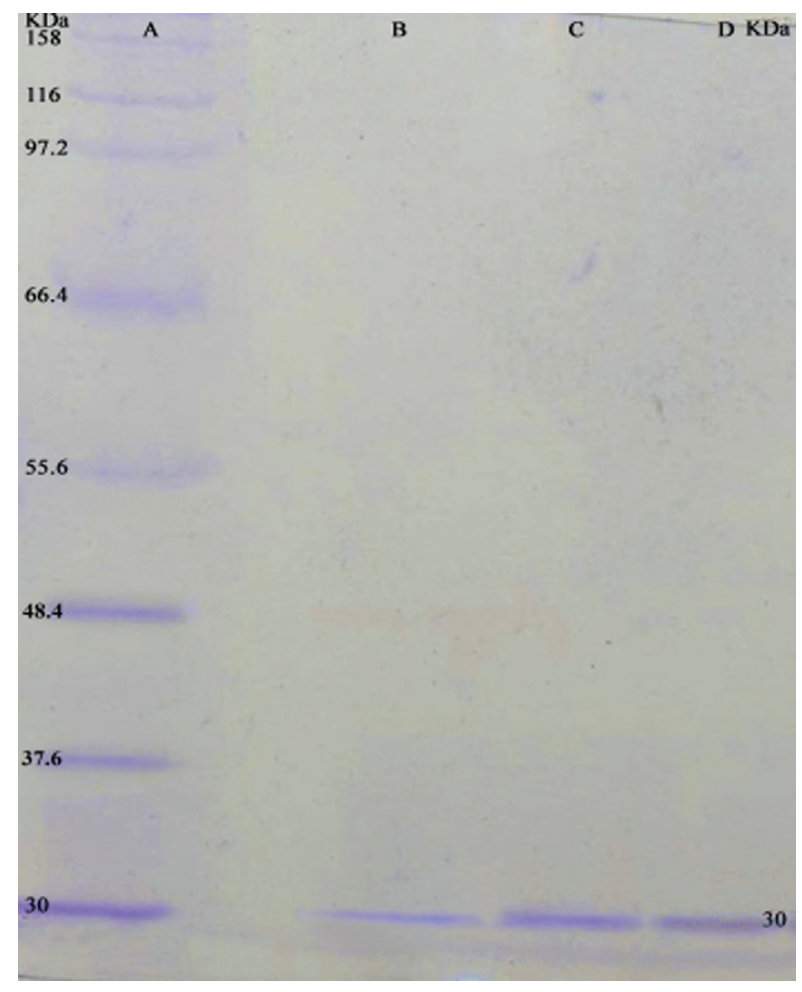

Figure 1. Determination of molecular weight of CIL by SDS-PAGE ( $12 \%$ gel with $1 \%$ SDS in the presence of $\beta$-mercaptoethanol). Lane A: Broad range molecular weight markers, Lane (B-D): 10, 15 and $20 \mu \mathrm{L}$ of purified CIL. A single band corresponding to $30 \mathrm{kDa}$ was obtained for CIL. 


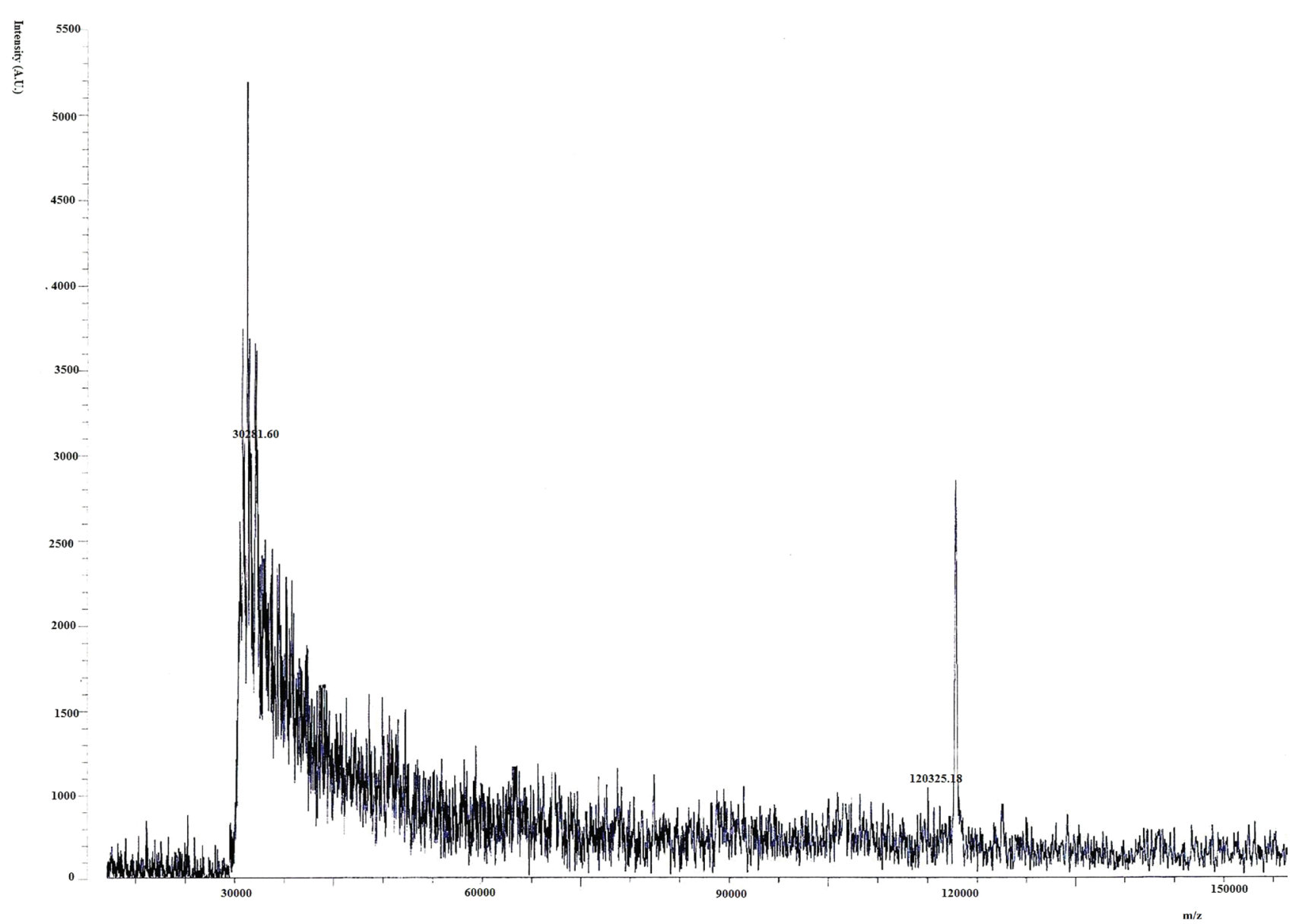

Figure 2. Determination of molecular weight of CIL by MALDI-TOF analysis using sinapinic acid as the matrix.

CIL is a basic lectin of $\mathrm{pI}$ 8.4. Subsequently the fractions were also assayed for haemagglutinationactivity. The haemagglutinationactivity vs $\mathrm{pHs}$ of the corresponding Rotofor fractions were summarized in the graph (Fig. 3).

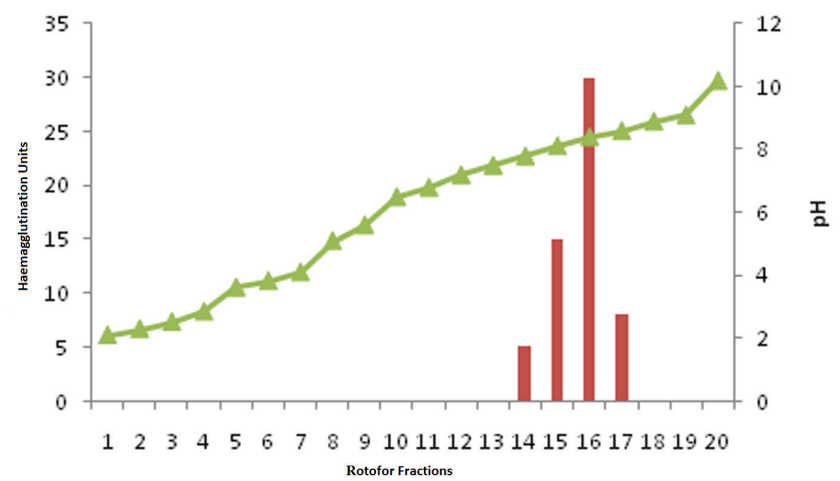

Figure 3. Iso-electric focusing profile of CIL by using Rotofor with gradual supply of a voltage from $300 \mathrm{~V}$ to 500 $\mathrm{V}$ for three hours.
4.4. Haemagglutination and Haemagglutination Inhibition Studies

The purified CIL agglutinated the trypsinised human RBCs in microtitre plate with visible agglutination mass. The NAG was strong inhibitor amongst the studied sugars with the minimum inhibitory concentration of about $0.97 \mathrm{mM}$. It was found that D-galactose and lactose showed haemagglutination inhibition at 5.60 and 7.80 $\mathrm{mM}$ concentrations. Other sugars such as D-fructose, D-mannose, D-galactosamine and D-arabinose showed characteristic minimal inhibitions when compared to non inhibitory sugars (NI) mentioned in Table 2. Glucose, maltose, D-fucose, D-ribose and sucrose were NI up to $300 \mathrm{mM}$ concentrations.

\subsection{Effect of Temperature and $\mathrm{pH}$ on Lectin-Induced Haemagglutination}

Thermal denaturation studies showed that CIL lost its agglutinating activity completely at $100{ }^{\circ} \mathrm{C}$ and $50 \%$ of activity lost at $50{ }^{\circ} \mathrm{C}$. The $\mathrm{pH}$ dependent studies on haemagglutination activity of CIL revealed that the 
Table 2. Haemagglutination inhibition assay of CIL with different sugars $(0.2 \mathrm{M})$ and their corresponding IC100 values.

\begin{tabular}{ll}
\hline Sugars studied & $\mathbf{I C}_{\mathbf{1 0 0}}(\mathbf{m M})$ \\
\hline N-acetyl-D-galactosamine & 0.97 \\
D-galactose & 5.6 \\
Lactose & 7.8 \\
D-fructose & 122.00 \\
D-mannose & 124.00 \\
D-galactosamine & 250.00 \\
D-arabinose & 250.00 \\
D-glucose, Maltose, D-fucose, & NI \\
D-ribose, Sucrose & \\
\hline
\end{tabular}

optimum $\mathrm{pH}$ for lectin activity was between $\mathrm{pH} 7$ and 8 respectively. In acidic of $<7$ and basic $\mathrm{pH}$ of $>8$ the haemagglutinating activity of lectin was greatly reduced (Fig. 4).

\subsection{Total Sugar Content of Lectin}

Total sugar estimation by Anthrone method gave sugar content of $8.8 \%$, at the initial protein concentration of $0.5 \mathrm{mg} \cdot \mathrm{mL}^{-1}$. The sugar concentration derived from the standard glucose plot was $0.044 \mathrm{mg} \cdot \mathrm{mL}^{-1}$.

\subsection{Antioxidant Activity Estimation by the DPPH} Radical-Scavenging Assay

The DPPH radical-scavenging ability of the CIL was determined and compared with the standard antioxidant, ascorbic acid. The free radical scavenging activity of CIL showed the $\mathrm{IC}_{50}$ value of $6.1 \pm 0.1 \mathrm{mg} \cdot \mathrm{mL}^{-1}$ while the standard ascorbic acid exhibited $5.7 \pm 0.1 \mathrm{mg} \cdot \mathrm{mL}^{-1}$.

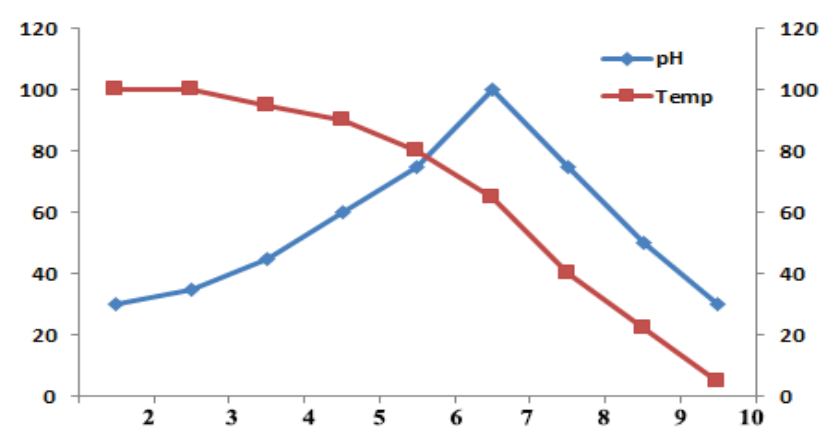

Figure 4. Effect of temperature and $\mathrm{pH}$ on the haemagglutination activity of CIL (2 mg.mL $\left.\mathrm{m}^{-1}\right)$. The hemagglutination activity was preserved at or below $50^{\circ} \mathrm{C}$ and at $\mathrm{pH} 7$ and 8

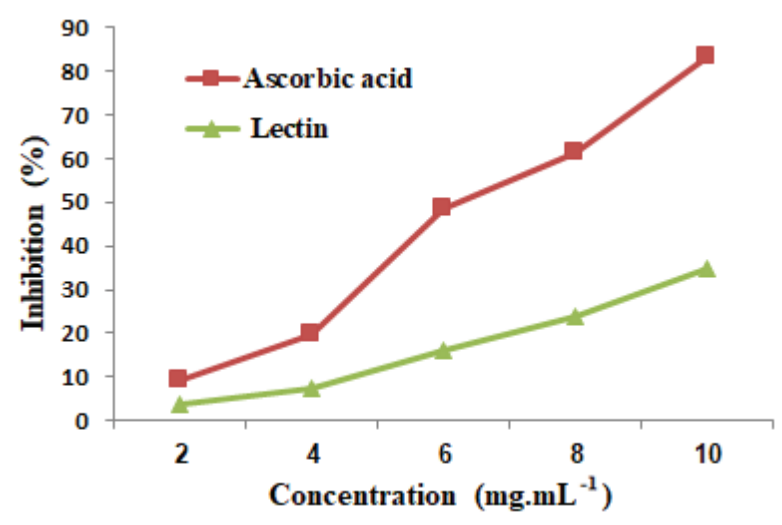

Figure 5. Estimation of antioxidant activity of CIL by using ascorbic acid (2-10 mg.mL $\mathrm{m}^{-1}$ ) as standard measured spectophotometrically at $517 \mathrm{~nm}$.

The CIL exhibited significant antioxidant activity when compared to the standard ascorbic acid (Fig. 5).

\subsection{Assay of Anti-Proliferative Activity on a Gastric Cancer Cell Line}

The in vitro MTT assay disclosed that treatment with CIL displayed anti-proliferative activity against gastric cancer cell line, AGS with $\mathrm{IC}_{50}$ of $82.8 \mu \mathrm{g}$. $\mathrm{mL}^{-1}$ showing inhibition of cell growth indicating a moderate anti-proliferative activity after incubation for about 48 hours (Fig. 6).

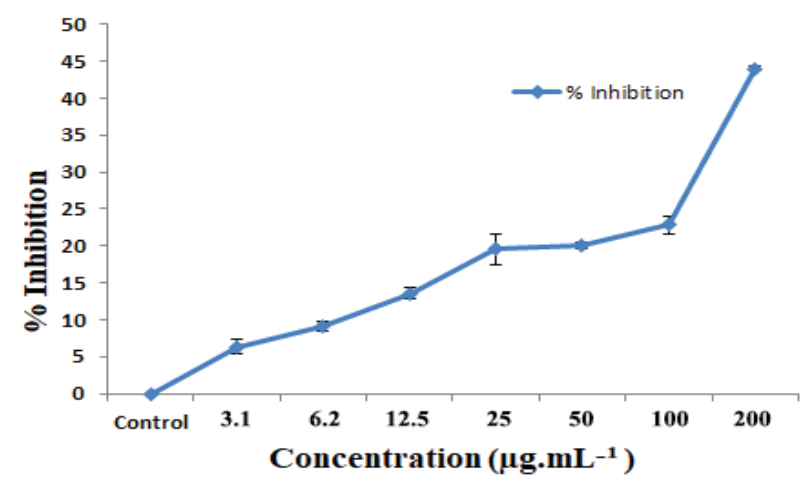

Figure 6. Determination of anti-proliferative activity of CIL against gastric cancer cell line, AGS and the optical density measured at $570 \mathrm{~nm}$.

\section{Discussion}

The legume lectins represent the largest and most thoroughly studied family of lectins with high sequence similarities, very similar tertiary structures and biophysical properties (45). Some species of Lamiaceae are used in folk medicines and lectins are widely distributed in them also $(46,47)$. Since the 
Clerodendrum infortunatum belongs to the Lamiaceae family, its lectin also sheds new incrementing light on the specificity, physiological role and evolution of the classical legume lectins. The purification strategy of CTA provoke us to characterize a novel lectin from Clerodendrum infortunatum with therapeutic potential (25). According to the literature, most of the CIL got precipitated in $40-80 \%$ of ammonium sulphate fraction with effective pigment removal by activated Toyopearl HW-55 (25). The SDS-PAGE and MALDI-TOF spectra revealed that CIL is a homotetramer of $120 \mathrm{kDa}$ consisting of four identical subunits of $30 \mathrm{kDa}$. The optimum $\mathrm{pH}$ of CIL was between 7 and 8 whereas its $50 \%$ of activity lost at $50{ }^{\circ} \mathrm{C}$, which correlates well with the previous reports (46).

The antioxidant activity reported for diverse species of Clerodendrum genus encouraged the assessment of free radical scavenging potential with CIL (20). Reports on the antioxidant activity of lectins are scares. The CIL exhibited moderate antioxidant activity with $\mathrm{IC}_{50}$ value of $6.1 \pm 0.1 \mathrm{mg} \cdot \mathrm{mL}^{-1}$. The trend showed that CIL moderately inhibited proliferation of AGS cell lines in a dose- and time-dependent manner and is obviously in the range with $\mathrm{IC}_{50}$ of $82.8 \mu \mathrm{g} . \mathrm{mL}^{-1}$ when compared with early known lectin reports. In fact, CIL is one among the few lectins by far presenting antitumor properties, as assumed from its anti-proliferative potential. The antitumor potential of Chinese pinto bean lectin (CPBL) against nasopharyngeal carcinoma, (HONE-1 cells), Lotus corniculatus lectin against human lung cancer cells (HCT116) and Phaseolus acutifolius agglutinin (PAA) against human colon adenocarcinoma cell line (Sw480) with $\mathrm{IC}_{50}$ values of $30.8 \mu \mathrm{M}, 60$ and $84.2 \mu \mathrm{g}$. $\mathrm{mL}^{-1}$ respectively has been reported earlier $(29,40-43)$.

\section{Conclusion}

The critical part involved in the purification of thenew lectin, CIL was the removal of pigments coexisting in the fruit, along with the lectin by Toyopearl HW-55. The lectin got precipitated in $40-80 \%$ of ammonium sulphate fractionation, followed by the effective purification with the Sephadex G-100 and the galactose coupled affinity column Sepharose-4B. The MALDITOF mass spectrum analysis, demonstrated CIL as a homo tetramer of $120 \mathrm{kDa}$. The purified CIL showed specificities towards different sugars like NAG, galactose and lactose in the decreasing order. The CIL exhibited DPPH radical-scavenging ability with $\mathrm{IC}_{50}$ value of $6.1 \pm 0.1 \mathrm{mg} \cdot \mathrm{mL}^{-1}$. The present study demonstrated the moderate ability of CIL to inhibit the growth of human gastric cancer cells, AGS either by causing cytotoxic or anti-proliferative effects with
$\mathrm{IC}_{50}$ of $82.8 \mu \mathrm{g} \cdot \mathrm{mL}^{-1}$. Thus, CIL may be considered as a potential candidate with biomedical applications in immunomodulation and tumor research. This was a basic approach and still more research, including in vivo analysis is desirable.

\section{Acknowledgements}

S.S acknowledges Department of Science and Technology (DST) for the financial support through DST-INSPIRE fellowship.MH gratefully acknowledges the Kerala State Council for Science, Technology and Environment for an Emeritus scientist's position.

\section{References}

1. Sharon N, Lis H. Lectins: cell-agglutinating and sugar-specific proteins. Sicence. 1972;177(4053):949-959.doi:10.1126.

2. Sharon N. Lectins: carbohydrate-specific reagents and biological recognition molecules. J Biol Chem.2007;282:27532764. doi:10.1074/JBC.X600004200.

3. Peumans WJ, Van Damme EJ. Lectins as plant defense proteins. Plant Physiol. 1995(2);109:347-352.doi: 10.1104.

4. Lis H, Sharon N. Lectins: Carbohydrate-specific proteins that mediate cellular recognition. Chem Rev. 1998;98(2):637-674. doi: $10.1021 / \mathrm{cr} 940413 \mathrm{~g}$.

5. Loris R. Principles of structures of animal and plant lectins. Biochim Biophys Acta. 2002;1572(2-3):198-208.

6. Sharon N, Lis H. How proteins bind carbohydrates: lessons from legume lectins. J Agric Food Chem. 2002;50(22):65866591.doi: $10.1021 / \mathrm{jf020190s.}$

7. Sharon N, Lis H. History of lectins: from haemagglutinins to biological recognition molecules. Glycobiology. 2004;14(11):53R-62R. doi:10.1093/glycob/cwh122.

8. Feizi T. Carbohydrate-mediated recognition systems in innate immunity. Immunol Rev. 2000;173(1):79-88. doi:10.1034/ j.1600-065X.2000.917310.x.

9. Liu B, Bian HJ, Bao JK. Plant lectins: potential anti-neoplastic drugs from bench to clinic. Cancer Lett. 2010;287(1):1-12. doi: 10.1016/j.canlet.2009.05.013.

10. Rini JM. Lectin structure. Annu Rev Biophys Biomol Struct. 1995;24:551-577. doi:10.1146/annurev.bb.24.060195.003003.

11. Liu B, Li C, Y, Bian H J, Min, MW, Chen LF, Bao JK. Antiproliferative activity and apoptosis-inducing mechanism of Concanavalin A on human melanoma A375 cells. Arch Biochem Biophys. 2009;482(1-2):1-6. doi:10.1016/j.abb.2008.12.003.

12. Fang EF, Lin P, Wong JH, Tsao SW, Ng TB. A lectin with antiHIV-1 reverse transcriptase, antitumor, and nitric oxide inducing activities from seeds of Phaseolus vulgaris cv. extralong autumn purple bean. J Agric Food Chem. 2010;58(4):22212229. doi:10.1021/jf903964u.

13. Schwarz RE, Wojciechowicz DC, Picon AI, Schwarz MZ, Paty PB. Wheatgerm agglutinin-mediated toxicity in pancreatic cancer cells. Br J Cancer.1999;80(11):1754-1762. doi:10.1038/ sj.bjc. 6690593 .

14. Valentiner U, Ian S, Schumacher U, Leathem AJ. The influence of dietary lectins on the cell proliferation of human breast cancer cell lines in vitro. Anticancer Res. 2003;23(2B):1197-1206.

15. Liu B, Zhang B, Mi MW, Bian HJ, Chen LF, Liu Q, Bao JK. Induction of apoptosis by Polygonatumodoratum lectin and its molecular mechanisms in murine fibrosarcoma L929 cells. 
Biochimicaet Biophysica Acta. 2009;1790(8):840-844. doi: 10.1016/j.bbagen.2009.04.020.

16. Panda PK, Mukhopadhyay S, Behera B, Bhol CS, Dey S, et al. Antitumor effect of soybean lectin mediated through reactive oxygen species-dependent pathway. Life Sci. 2014;111(1-2):2735. doi: 10.1016/j.lfs.2014.07.004.

17. Kiss R, Camby I, Duckworth C, De Decker R, Salmon I, et al. In vitro influence of Phaseolus vulgaris, Griffoniasimpliciflia, Concanavalina A, Wheat germ, and peanut agglutinin on HCT15, Lovo, d SW 837 human colorectal cancer cell growth. Gut. 1997;40(2):253-261.

18. Lei HY, Chang CP. Induction of autophagy by concanavalin A and its application in antitumour therapy. Autophagy, 2007;3(4):402-404.doi: 10.4161/auto4280.

19. Rohman A, Riyanto S, Yuniarti N, Saputra WR, Utami R, Mulatsih W. Antioxidant activity, total phenolic, and total flavaonoid of extractsand fractions of red fruit (Pandanus conoideusLam). Int Food Res J. 2010;17:97-106.

20. Bhattacharjee D, Das A, Das SK, Chakraborthy GS. Clerodendruminfortunatum Linn: A Review. J Adv Pharm Healthcare Res. 2011;1:82-85.

21. Manzoor KM, Sarela S. Constituents of clerodendruminfortunatum (bhat)- I: Isolation of clerodolone, clerodone, clerodol and clerosterol. Tetrahedron. 1965;21(4):797-802.

22. Rajakaruna N, Harris CS, Towers GHN. Antimicrobial activity of plants collected from Serpentine outcrops in Sri Lanka. Pharm Biol. 2002;40(3):235-244. doi: 10.1076/phbi.40.3.235.5825.

23. Rajurkar BM. Morphological study and medicinal importance of Clerodendruminfortunatumgaertn. (verbenaceae), found in Tadoba national park, India. JPRHC. 2010;2(2):216-220.

24. Rajurkar BM. Phytopharmacological investigation of Clerodendruminfortunatumgaertn. IRJP2011;2(11):130-132.

25. Kitagaki H, Seno N, Yamaguchi H, Matsumoto I. Isolation and characterization of a lectin from the fruit of Clerodendrumtrichotomum. J Biochem.1985;97(3):791-799. doi:10.1093/oxfordjournals.jbchem.a135119.

26. Matsumoto I, Ito Y, Seno N. Preparation of affinity adsorbents with Toyopearl gels. J Chromatogr. A.1982;239:747-754. doi: 10.1016/S0021-9673(00)82034-8.

27. Franco FL, Batista VF, Carlsson J. Isolation of a ß-galactosidebinding lectin from cat liver. Braz J Med Biol. Res. 2003; 36 (4): 447-457. doi: 10.1590/S0100-879X2003000400005.

28. Yeasmin T, Tang MAK, Razzaque A, Absar N. Purification and characterization of three galactose specific lectins from Mulberry seeds (Morus sp.). Eur J Biochem. 2001:268(23)60056010.doi:10.1046/j.0014-2956.2001.02470.x.

29. Ang ASW, Cheung RCF, Dan X, Chan YS, Pan W, et al. Purification and characterization of a glucosamine-binding antifungal lectin from Phaseolus vulgaris cv. Chinese Pinto Beans with antiproliferative activity towards nasopharyngeal carcinoma cells. Appl Biochem Biotechnol.2014;172:672-686.

30. Zhang W, Tian G, Geng X, Zhao, Y, Ng TB, Zhao L, Wang $H$. Isolation and characterization of a novel lectin from the edible mushroom Strophariarugosoannulata Molecules. 2014;19(21):19880-19891.doi: 10.3390/molecules191219880.

31. Weber K, Osborn M. The reliability of molecular weight determinations by Dodecyl Sulfate-Polyacrylamide Gel Electrophoresis. J Biol Chem.1969;244:4406-4412.

32. Laemmli,UK. Cleavage of structural proteins during the assembly of the head of bacteriophage T4. Nature.1970;227:680-685. doi:10.1038/227680a0.

33. Lin JY, Lee TC, Hu ST, Tung TC. Isolation of four isotoxic proteins and one agglutinin from jequiriti bean (Abrusprecatorius). Toxicon. 1981;19(1):41-51. doi: .1016/0041-0101(81)90116-1.

34. Atkinson HM, Trust TJ. Hemagglutination properties and adherence ability of Aeromonashydrophila. Infect Immun. 1980;27(3):938-946.

35. Hedge JE, Hofreiter BT. Methods, In: Carbohydrate Chemistry by Whistler RL, BeMiller JN, editors. New York: Academic Press; 1962.p. 420.

36. Paixao N, Perestrelo R., Marques JC, Camara JS. Relationship between antioxidant capacity and total phenolic content of red, rose and white wines. Food Chem. 2007;105(1):204-214. doi: $10.1016 / j$.

37. Nikolova M. Screening of radical scavenging activity and polyphenol content of Bulgarian plant species. Pharmacogn Res. 2011;3(4):256-259.doi: 10.4103/0974-8490.89746.

38. Brand-Williams W, Cuvelier ME, Berset C. Use of a free radical method to evaluate antioxidant activity. Food Sci Technol1995;28(1):25-30. doi: 10.1016/S0023-6438(95)800085.

39. Lin P, Wong JH, Ng TB, Ho VS, Xia L. A sorghum xylanase inhibitor-like protein with highly potent antifungal, antitumor and HIV-1 reverse transcriptase inhibitory activities. Food Chem. 2013;141(3):2916-2922. doi: 10.1016/j.foodchem.2013.04.013.

40. Rafiq S, Majeed R., Qaz,i AK, Ganai BA, Wani I, Rakhshanda S, Qurishi Y, Sharma PR., Hamid, A, Masood A, Hamid R. Isolation and antiproliferative activity of Lotus corniculatus lectin towards human tumour cell lines. Phytomedicine. 2013;21(1):30-38.doi: 10.1016/j.phymed.2013.08.005.

41. Valadez-Vega C, Alvarez-Manilla G, Riveron-Negrete L, Garcia-Carranca, A, Morales-Gonzalez J. A, Zuniga-Perez C, Madrigal-Santillan E, Esquivel-Soto J, Esquivel-Chirino, C, Villagómez-Ibarra R, Bautista M, Morales-Gonzalez A. Detection of cytotoxic activity of lectin on human colon adenocarcinoma (Sw480) and epithelial cervical carcinoma (C33-A). Molecules, 2011;16(3):2107-2118.doi: 10.3390/ molecules 16032107.

42. Valadez-Vega C, Guzman-Partida AM, Soto-Cordova FJ, Alvarez-Manilla G, Morales-Gonzalez JA, et al. Purification, biochemical characterization, and bioactive properties of a lectin purified from the seeds of White tepary bean (Phaseolusacutifolius, VarietyLatifolius). Molecules, 2011;16(3):2561-2582. doi: 10.3390/molecules16032561.

43. Hamid R, Masood A, Wani IH, Shaista RS. Lectins: Proteins with Diverse Applications. J App Pharm Sci. 2013;3:93-103. doi: 10.7324/JAPS.2013.34.S18.

44. Lannoo N, Van Damme, EJM. Lectin domains at the frontiers of plant defense. Front. Plant Sci. 2014;5:397. doi: 10.3389/ fpls.2014.00397.

45. Ambrosi M, Cameron NR, Davis BG. Lectins: Tools for the molecular understanding of the glycocode. Org Biomol Chem. 2005;3(9):593-1608. doi: 10.1039/B414350G.

46. Perez G, Vega N. Lamiaceae lectins. Funct Plant Sci Biotechnol. 2007;1(2):288-299.

47. Wang W1, Peumans WJ, Rougé P, Rossi C, Proost P, Chen J, Van DammeEJ.Leaves of the Lamiaceae species Glechoma hederacea (ground ivy) contain a lectin that is structurally and evolutionary related to the legume lectins. Plant J. 2003;33(2):293-304. doi: 10.1046/j.1365-313X.2003.01623.x. 